These are relatively small criticisms and it is hoped that readers will not take them as a condemnation of the book. Frazer's Anatomy of the Human Skeleton remains an excellent treatise which can be wholeheartedly recommended to undergraduates, medical students, postgraduate students and anatomists alike. It gives a refreshing and stimulating approach to the subject of osteology, and indeed to anatomy as a whole, which is not found in any other textbook.

\section{PRACTICAL ALLERGY}

By M. Coleman Harris, M.D., F.A.C.P. and Norman Shore, M.D., M.S., F.A.C.P. Pp. xiii +47 I, with 25 illustrations. London: Butterworth \& Co. Ltd. I958. 52s. 6d.

This book sets out to provide practical information for physicians and general practitioners interested in treating allergic disorders, rather than for allergists.

The authors are careful to define what they mean by allergy, and describe the differences between the immediate and the delayed types of allergic reaction.

The book describes in detail the approach to allergic diagnosis, rightly stressing careful historytaking rather than skin tests. It goes on to describe the common allergies and their management. Detailed pollination season tables are only given for the United States, although brief ones for Britain are given.

The authors include 40-odd pages on miscellaneous diseases, including the collagenoses, in which they admit that the allergic origin is not yet fully proven. As in practice the management of these diseases is not anti-allergic they could have been omitted.

The book can be recommended as a readable and informative book on allergy for the non-allergist.

A.W.F.

\section{MODERN TRENDS IN PAEDIATRICS Second Series}

Edited by A. Holzel and J. P. M. Tizard. Pp. xxiii +372 with 46 illustrations. London: Butterworth \& Co. Ltd. I958. 70s.

This is the most important and stimulating large book in the field of paediatrics which has been published since the war. The majority of the contributors are young and each has succeeded admirably in fulfilling the two tasks set him by the editors: to survey a subject of growing importance and to speculate about possible future developments.

The chapters on genetics and child psychiatry are both fascinating and challenging. At the moment 46 per cent of the hospital beds in this country are occupied by mental patients-either mentally retarded or disordered. The discovery of genetically determined biochemical abnormalities is already offering prospects of amelioration of one or two types of mental defect; but, as yet, attempts at eugenic control are hardly justifiable. On the psychiatric side it is at long last becoming generally recognized that the only time to prevent people growing up with sexual deviations or prevent adults getting psychotic illnesses is by detecting and treating the abnormalities in the early stages, i.e. in the first few years of life. British paediatricians have, on the whole, been slow to realise this and it is welcome to see such support to this view here. Although the need for personal psychoanalysis of the doctor is overstressed, there can be no belittling of the important lessions which psychoanalysis can teach the paediatrician.

The chapter on congenital heart disease is wisely selective and shows that any further significant reduction in mortality means diagnosis and treatment in the first year of life.

The sections on corticosteroids and on mineral metabolism both distil the essentials from a literature which has become uncomfortably vast.

The only chapters which do not quite reach the high standards of the rest of the book are those on neonatal pathology and allergy. In their different spheres, each fails to pin-point the real problems.

Three interesting chapters on the work of a provincial paediatrician in the U.S.A., U.S.S.R., and U.K. reflect the different national approaches to medicine.

Other good contributions are on vital statistics, anoxia, neonatal surgery, haematology, virus diseases, malignant diseases, convulsions, neurosurgery, chromatography, radiocative isotopes and physical growth.

\section{TEXTBOOK OF BRITISH SURGERY}

Edited by Sir Henry Souttar, C.B.E., D.M., F.R.C.S., and J. C. Goligher, Ch.M., F.R.C.S. Volume Three. Pp. viii + 6rg, with 206 illustrations. I958. I05s. London: William Heinemann Ltd.

Publication of the third volume completes this fine work. In this volume pride of place has been given to genito-urinary surgery and peripheral vascular diseases. Amongst the other subjects are the surgery of the adrenal and parathyroid glands; radiology and radiotherapy, and fluids and electrolytes. The high standard of the previous two volumes has been fully maintained. This work is strongly recommended.

\section{THE TISSUES OF THE BODY}

\section{An Introduction to the Study of Anatomy}

By W. E. Le Gros Clark, F.R.S. Fourth edition.

Pp. xi +415, I 27 figures. I 958 . 40s. London:

The Clarendon Press.

Since its first appearance in 1939 ' The Tissues of the Body' has become firmly established as one of the most stimulating text-books which can be put into the hands of the medical student. As an introduction to the study of anatomy it was at that time revolutionary, making a clean break with the 
tradition that the basis of anatomy was an intensive study of topographical detail at the macroscopic level. The student's attention was reoriented towards the living tissues of which the body is composed, and inspired by being brought 'to vantage points on the advancing front of scientific adventure,' to quote the preface to this $4^{\text {th }}$ edition. Partly as a result of the emphasis which had been placed on the study of macroscopic detail, the research and teaching interests of anatomists had become almost completely divorced. This book has done more than any other to bring them together, and to show students that anatomy is a living and advancing science as satisfying to an active intelligence as any other.

The $4^{\text {th }}$ edition has preserved the admirable qualities of its predecessors. Some new material has been added and parts have been rewritten. A number of the most recent advances, e.g. those resulting from the use of the electron microscope, are now included, but it is pleasant to see that the changes have increased its size by no more than a few pages. It still remains the best introduction to the study of anatomy, and can also be read with both pleasure and profit by those whose anatomical studies lie mainly in the past.

\section{INTRODUCTION TO DENTAL ANATOMY}

By J. H. ScotT, D.Sc., M.D., L.D.S. and N. B. B. Symons, M.Sc., B.D.S. Second edition. Pp. $\mathrm{xi}+344$, with 219 illustrations. Edinburgh: E. \& S. Livingstone, Ltd. I 958.2 gns.

Messrs. Scott and Symons have now made an Introduction to Dental Anatomy into a comprehensive survey of the subject. This has been achieved by adding a section dealing with the macroscopical study of human teeth; by re-editing, and in many instances, re-writing the text of the first edition.

The continuity of the book makes it very ' readable' and the photographs and diagrams are of high quality, although in the first chapter on the Form and Relations of Human Teeth, the detail photography is not quite up to standard of the remainder. However, as every student should have a set of natural teeth to study in conjunction with the text, this is only a minor fault.

An excellent textbook both for students and as preparatory reading for postgraduate study, the comprehensive references being particularly useful in this respect.

J.N.

\section{THE CEREBROSPINAL FLUID}

Production, Circulation and Absorption

Edited by G. E. W. Wolstenholme, O.B.E., M.A., M.B., B.Ch., and Cecilia M. O'ConNor, B.Sc. Pp. xii +335 , illustrated. 1958. 50s. London: J. \& A. Churchill Ltd.

This book is the report of a Ciba Foundation
Symposium and is concerned with the production, circulation and absorption of the cerebrospinal fluid, although this necessarily requires a considerable amount of anatomy. The chapters are by a distinguished series of contributors and it forms a most valuable summary of the recent work on the subject.

It is lavishly illustrated and because the illustrations are so frequent the entire book has been produced on glossy paper. There are, however, certain faults in editing and it is irritating to have a black and white illustration, e.g. on page 128 , which has a caption telling one that the arteries are outlined in blue and the veins in red. In spite of this minor criticism the book is strongly recommended.

K.W.C.

\section{CHEMICAL METHODS IN CLINICAL MEDICINE}

By G. A. Harrison, M.D., F.R.I.C. Fourth Edition. Pp. 667, figs. 158. London: J. \& A. Churchill Ltd. 65 s.

Ten years have elapsed since the last edition of this standard work appeared. Dr. Harrison has added a great deal of new material but managed to compress it into few extra pages. There are welcome new accounts of photo-electric absorptio meters and of the flame photometer (it is a pity that the author still clings to milligrammes in de scribing sodium and potassium standards). Chro matography and electrophoresis are described: The author's prejudice against the estimation of the I 7-ketosteroids in urine seems hard to justify. Here and there certain changes of fashion might have led to changes of emphasis: few clinicians now bother with the urea concentration test for example, while PSP excretion, which is dismissed in three lines, is estimated in most American laboratories. The author's views on diabetes are unorthodox; it is surprising to find that mild diabetics should either be warned not to lose weight (p. 193) or told to maintain it (p. 194) when a large number of obese patients with glycosuria regain normal carbohydrate tolerance when weight is reduced, a fact which is not mentioned. The section on diabetic coma is valueless and would be better omitted. There is a short section on intravenous fluids; it might with advantage include some notes on potassium therapy; the author's only reference to a paper on post-operative fluid and electrolyte therapy is dated 1938 . The section on liver function tests is more topical, but most workers would like to see a description of the thymol turbidity test included, though the author appears to have no use for it.

These shortcomings do not detract from the value of the book as a whole. Comprehensive and clearly written, beautifully produced and inexpensive, it must remain a necessary standby in every routine laboratory. 